\title{
Modest increases prevail in Japanese budget bids
}

[TOKYO] Japanese science agencies are asking for modest budget increases next year, in the knowledge that the finance ministry will no longer support the sharp rises in funds for research they have enjoyed in recent years.

This marks a clear departure from a government plan set last year, which called for an increase in budget for science and technology of more than 50 per cent over the forthcoming five years (see table below). It also shows that the government's recent moves to restructure the nation's ailing finances are taking precedence over the plan.

The Ministry for International Trade and Industry (MITI) has requested an increase of about 5 per cent, while the Science and Technology Agency (STA) asked for only a 1.4 per cent increment. Overall, the increases for the various science-related ministries and agencies are less than half the percentage rises obtained this fiscal year, and, together with the 'scrap and build' philosophy advocated by the Ministry of Finance to encourage greater flexibility in spending, they may force ministries and funding agencies to look hard at the quality and efficiency of their research funding programmes.

Among the more visible items in this year's budget request is a proposal by the STA to set up a genome research centre inside the Institute for Physical and Chemical Research (Riken), where the STA has been supporting efforts in automated genome sequencing and genome research since the late 1980s.

The STA expects the centre to fulfil a coordinating role in genetic research in Japan. But some researchers are not impressed, pointing out that earlier efforts in automated genome sequencing at Riken have failed and that most of Japan's genome research is $\begin{array}{r}\text { Highlights of } 1998 \text { budget requests } \\ \hline \begin{aligned} 1998 \text { request } & \text { Percent } \\ \text { ( } ¥ \text { billion) } & \text { change }\end{aligned}\end{array}$

Science and Technology Agency (STA) Total R\&D budget requested $745.0+1.4 \%$ Genome research $\quad 6.9+171 \%$ Brain research $\quad 13.9+40 \%$ Global environmental research $63.7+14 \%$ $\begin{array}{ll}\text { Space research } & 183.2+1 \%\end{array}$ Nuclear fuel cycle R\&D $\quad 205.4 \quad-10 \%$

Ministry for Health and Wellfare (MHW) Total research funds $\quad 92.3+1 \%$ Medical genetics $\quad 2.5$ Research on dioxins $\quad 1.5$

\begin{tabular}{|c|c|c|}
\hline \multicolumn{3}{|c|}{$\begin{array}{l}\text { Ministry of International Trade and } \\
\text { Industry (MITI) }\end{array}$} \\
\hline Total R\&D budget request & 499.2 & $+5.7 \%$ \\
\hline Genome research & 2.1 & $+350 \%$ \\
\hline $\begin{array}{l}\text { Public sector/industry } \\
\text { cooperation }\end{array}$ & 6.3 & $+262 \%$ \\
\hline Renewable energy & 16 & $+36 \%$ \\
\hline Innovative industrial technology & 30.5 & $+9 \%$ \\
\hline Patent system upgrade & 60 & $+20 \%$ \\
\hline Nuclear power & 23 & $-8 \%$ \\
\hline
\end{tabular}

concentrated in the universities.

The proposed research centre is part of a coordinated effort to bring together research support schemes in information technology, environmental science, and the life sciences at various ministries. MITI is expected to support innovative software products for protein modelling, while the Ministry for Agriculture, Forestry, and Fishery plans to pursue a second, application-oriented, phase of its rice genome project. The Ministry of Health and Welfare has requested increased funding for research on genetic diseases.

Following the same pattern of joint ministry projects, the Ministry of Health and Welfare and the Environmental Agency will reinforce basic and applied research on the public health impact of dioxins. The government revised maximum exhaust standards for dioxins earlier this year, after reports of high dioxin values around Japan's numerous waste-incineration facilities.

Japanese ministries have used the occasion of the International Climate Conference, to be held in Kyoto in December, to request increases for research on global environmental issues. MITI also wants to reinforce government support for renewable energy, efficient furnaces and clean cars.

Earlier this month, after a proposal by the independent Science Council of Japan, the education ministry announced plans to set up centralized research facilities for environmental research and computer science. But the ministry has kept funding requests for both institutions low-key.

The great losers in this year's budget request are large-scale technology development efforts in nuclear energy and space. Nuclear energy research at both MITI and STA has been cut sharply. Earlier this year, Japan's National Space Development Agency faced the prospect of the smallest budget increase for years, and this has already resulted in the redefinition or demise of several projects (see Nature 388, 615: 1997).

The STA is also seeking approval to create new administrative positions. These include five new staff each to manage the transition of the troubled Power Reactor and Nuclear Fuel Corporation (PNC) into a new entity and to upgrade the agency's research evaluation scheme. The STA also wants to create a bioethics-related position inside its life science department.

Overall, the budget requests appear to recognize what critics of the country's public research infrastructure have asserted for some time: that Japan should improve the quality and strategic orientation its research, rather than simply expanding funding. Robert Triendl

\section{Scripps Institute plan would boost research space}

[SAN DIEGO] The Scripps Research Institute is planning a major expansion at La Jolla, California, aiming to consolidate research facilities on one site and to take on more staff.

The proposal has provoked opposition from doctors working at the hospital that would be closed to clear the way for more laboratories. Research space at the site would increase by about 50 per cent under the plan being considered by the its parent board, the Scripps Institutions of Medicine and Science, which also operate six hospitals in the region.

If approved, the institute's expansion could enhance a burgeoning research community in the area - nearby are the Salk Institute; the University of California at San Diego (UCSD); the Burnham Institute (formerly La Jolla Cancer Research Foundation); the Sidney Kimmel Cancer Center; and numerous biotechnology companies.

Richard Lerner, president of the institute, has said the plan will further his goal of making Scripps "the finest research institute in the world".

The institute, which has an annual operating budget of $\$ 160$ million, occupies about 500,000 square feet of laboratory space at the La Jolla site and leases about 250,000 square feet elsewhere. Scientists working at these offsite laboratories would be able to move to La Jolla if the research complex were expanded - a process that would take up to five years.

The plan is to close the 170-bed Green Hospital, adjacent to the institute, and combine it with the nearby, 321-bed Scripps Memorial Hospital, across the street from UCSD's new Thornton Hospital. The San Diego region has too many hospital beds and has experienced major cuts in health insurance companies' payments for care.

The proposal has prompted deep concern among the physicians at the renowned Scripps Clinic Medical Group, the 290-doctor team that provides care at the Green Hospital. The close-knit group fears that the new arrangement would detract from its method of treating patients. Dr. Thomas A. Waltz, a neurosurgeon who heads the group, says: "We do not have a knee-jerk reaction, saying: 'No, no, never'. But there are a large number of issues that no one has begun to consider."

But financial pressure is likely to force the move. It would allow the institute to add further to recent recruits, who include Paul Schimmel, a biochemist from Massachusetts Institute of Technology (MIT); Jeff Kelly, a chemist from Texas A\&M; Jamie Williamson, a nuclear magnetic resonance specialist, also from MIT; and Williamson's wife Martha Fedor, a biologist from the University of Massachusetts. 